\section{Teaching English Speaking Skill through Pair and Group Interview Techniques}

\author{
1 Sudirman Maca \\ 1 Universitas Bosowa, Indonesia
}

\begin{abstract}
The problem that the participants face in the speaking class teaching is very low confident in speaking English in the class. The research aims are to find the effectiveness the pair and group interview techniques to enhance the participants' speaking skill. The experimental study consisting 100 participants at fourth semester of Educational English Department Bosowa University and 40 participants have been chosen randomly as a sample which divided into the treatment class and control class. The treatment class was divided into pairs and groups in conducting the three types of interview techniques in which, one participant asking the four participants and four participants asking one student. The study reveals that the participants felt free and brave expressed their language skill through the small group both pairs and groups of interview techniques. Moreover, these result also was identified that these techniques effective stimulating the participants to speak English actively, confidently, and fluently than the traditional teaching model. In which, all the treatment class, most the participants speaking English actively, whereas the control class is only 60 percent participants speaking English actively and some of the participants only kept silent in the class.
\end{abstract}

\section{Keywords}

speaking

interview techniques

pairs and groups

\section{Ethical Lingua}

Vol. 7, No. 2, 2020

ISSN 2355-3448 (Print)

ISSN 2540-9190 (Online)

Corresponding Email

Sudirman Maca

sudirmanmaca@gmail.com

Article's History

Submitted 8 July 2020

Revised 25 September 2020

Accepted 25 September 2020

DOI

10.30605/25409190.192

Copyright (๑) 2020

The Author(s)

This article is licensed under CC BY-NC-SA 4.0 License

\section{(cc) EY-NC-SA}




\section{Teaching English Speaking Skill through Pair and Group Interview Techniques}

Mastering language is more important in the communication. Language functions are as the tools of communication in human interaction among the people in the word communities. In language acquisition, have four categories that the students have to acquire such as: speaking, listening, writing, and reading competences. Oral communication is the core of the language in the oral interaction. Esmaeeli, Sabet, \& Shahabi (2018) state that the EQ question can be implemented to improve the speaking ability in language classroom. Nation (1977) encourages the English as Foreign Language (EFL) teachers in order to divide the big class into groups in which four or five students in each group involve their speaking skill practicing, conversation plans, and free conversation. Moulton (1961), states that language as oral communication is the main point of interaction, mastery the oral communication need to be studied as the language that native speaker's utterance not as thought but have to be speak out as different language. Minimal pairs is effectiveness to be employed as the teaching model in improving the English speaking skill (Tuan, 2010).

Sura (2012) states the types of speaking groups, the group of the native language use in speaking small groups, the competence of the speakers as successful teaching process. When the teacher asks the leaners to utter their language skill in the traditional class, the students cannot perform their language properly. They do not have motivation to speak to the others. But, when the students are given topics and types of question both in pairs and groups, they began to perform their language enthusiastically.

The researcher formulated the questions as follows: 1). To what extent do the pair and group interview techniques effective stimulating the learners' English competences? 2). How are the students' responses toward the pair and group interview techniques?

The significant of the research is expected has significant contribution both theoretical and practically in teaching models. The research result has contribution improving the teaching approach in the English speaking class. The research also has contribution model to the leaners and teachers to teach English speaking skill in the speaking class.

Teng (2020) states that the students in group work more knowledge of vocabularies than doing the tasks in a pair; however, activities in pairs drive to be better competence than individual activities. Furthermore, Harkness, et al. (2003), found that interview is good technique improve speaking skill. Potaka, et al. (2004). Found that questioning words effective enhance speaking skill.

Martinez, et al. (2003) conducted their attitudes research of Ph.D. students toward group work in Indiana University. The research finding that the students have good attitudes toward the group work. Liao (2009) found that using certain technique and interesting topic can stimulate the students to speak English fluently. Furthermore, Rakab (2016) states that communication practice can stimulate the language acquisition, and also reveal that communicative activities motivated the students to negotiate for meaning. So, using PW and GW models are better for learning process in language mastery. Cahya (2017) conducted the study of motivation and reveals that it has relation to the second language motivation to the 
EFL learner competences. The students have strong motivation in learning English got better achievement in EFL proficiency.

The small groups will give chance to the learner gives opinion in the discussion, also the regulation as possible. The strength of group in small number will give the member braveness to express their idea of purposes. Thayyib's (2019) studies of group dynamics through Lesson Study shows that the group members did all group activities orders and the participants understood of materials for group work and the other learning facilities to the groups.

Richard (2008), states that small group discussion is the good model to express idea orally, and work together among the members. Moreover, De Bot \& Lowie (2005), states that languages are learned mainly through informal interaction. Labov (2006), states that interview in term of contextual style is this effective in standardizing the relative shifts of language behavior which occur in our daily activities.

Teachers prepare some techniques in the class of speaking skill such a debating. Furthermore, Lehmann (2006), states that the active speaking class is influenced by understanding the students' culture of group. Most of the students are interested in formal and informal education, universities responsible to the students' skills and abilities. The different strategies and model have been conducted in class to support the students' skill achievement (Soldado et al., 2013).

The purposed of this research is to identify the effectiveness of pair and group interview techniques enhance the learners can enhance their speaking freely, actively, and more confidently in their community.

\section{Method}

The researcher conducted the experimental research in of pair and group interview techniques. The sample was taken into small numbers of group they are control group and treatment group. The independent variable is "pair and group Interview Techniques" which has contribution in stimulating the participants to utter their oral competences. The dependent variable was the students of Faculty of Education Bosowa University. The indicators that used in this research are Interviewer asking some questions in English, interviewees responding the questions. The participants also could make some of different questions to enhance their English competence.

The population of the study was 100 students of fourth semester at Education faculty of Bosowa University, South-Sulawesi. The research sample was taken randomly through based on the students' number consists of 40 students. They were divided into control and treatment in which each group consisted of 20 participants. They are three instruments in this study they are questionnaire, video recording, and observation checklist.

The treatment class was distributed the four topics and the facilitators explained the regulation in the study process: First type of the interview. In applying pairs group, the participants were grouped to pace to pace. They choose the topics and then involve the interviewing practicing for thirty minutes. One participant acted as interviewer and other participant acted as interviewee vice versa. Second type, there were four groups in which five participants for every group. One participant acted as an interviewer and four participants acted as interviewees by choosing the topics. The first session was one participant interviewed the 
four participants. The second session was one participant acted as interviewee and four participants acted as interviewers for thirty minutes too.

The data were recorded through video recording in the groups interviewing activities. The data were analyzed through observation checklist. The questionnaire was distributed to all the participants to get the participants' positive and negative attitude of the pair and group interview techniques.

The data are presented through quantitative and qualitative descriptive statistics. The questionnaire data were analyzed through Likert scale they are; strongly agree, agree, undecided or doubtful, disagree, and strongly disagree. Classification scores as follows: Strongly agree $=5$, Agree $=4$, Undecided $($ doubtful $)=3$, Disagree $=2$, Strongly disagree $=$ 1, (Gay, 1981:126). The data collected through questionnaire were analyzed through the pattern of analysis, (Gay, 1981:298). The observation checklists data were analyzed to identify the active participants speaking competence toward the pair and group interview techniques. The participation categories are; a. Very active: Used English whole interview session. b. Active: Used English almost the whole interview session c. fairly active: Used English combining Bahasa in the interview session d. less active: Used Bahasa most of the interview session. Non active: Used Bahasa whole interview session

The data were analyzed by using responses model pattern:

Participants' Activities $=$

Number of participants who give responses actively

The total of participants who give responses $\mathrm{X} 100 \%$

\section{Results}

\section{Experimental Class}

\section{Students' Attitude through Questionnaire Data}

The data were collected through of 20 numbers questionnaire; 10 items aim at getting the participants' positive attitude, and rest 10 items to get the participants' negative attitude through pair and group interview techniques. The mean score shows 92.85 percent, in which the students' positive attitude means score is 47.55 percent and negative attitude mean score is 45.30 percent. It means that the students have very high attitude through group interview techniques.

\section{Students' Activities through Observation checklist data}

There are three types of checklist used to identify the active participant in applying the pairs and groups interview techniques. The data analyses were shown in the following data.

\section{The first type of interview technique}

This pair types are face to face technique, where the students are divided into ten groups. Each group consists of two participants sitting face to face. One of participant became interviewer and one participant became interviewee and vise-versa. The interview took 30 minutes. The data of active participants in which acted as interviewers and interviewees were recorded in table 1 as follows: 
Table 1. The active participants of the interview in pairs

\begin{tabular}{llllll}
\hline No. & Qualification & $\begin{array}{l}\text { Interviewer } \\
\text { Frequency } \\
\text { (Students) }\end{array}$ & $\begin{array}{l}\text { Percentage } \\
(\%)\end{array}$ & $\begin{array}{l}\text { Interviewee } \\
\text { Frequency } \\
\text { (Students) }\end{array}$ & $\begin{array}{l}\text { Percentage } \\
(\%)\end{array}$ \\
\hline 1 & Very Active & 10 & 100 & 10 & 100 \\
2 & Active & 0 & 0 & 0 & 0 \\
3 & Fairly Active & 0 & 0 & 0 & 0 \\
4 & Less Active & 0 & 0 & 0 & 0 \\
5 & Silent & 0 & 0 & 0 & 0 \\
\hline Total & 10 & 100 & 10 & 100 \\
\hline
\end{tabular}

In this type of interview, the data analysis shows all of the students $20(100 \%)$ students very active as interviewer and interviewees, none of the students passive, in asking questions through the pair interview techniques. They were not confused or silent. They speak more fluent, enthusiastic and confident in speaking in English.

\section{The second type of interview technique}

In this second interview technique type, the participants were divided into four groups. Each group consists of five participants sitting in round. One participant became interviewer and four participants became interviewees. The participants conducted the interview for 30 minutes by taking one topics. The active participants of interviewers and interviewees were recorded in the table 2 as follows:

Table 2. The active participants of the interview in group

\begin{tabular}{llllll}
\hline No. & Qualification & $\begin{array}{l}\text { Interviewer } \\
\text { Frequency } \\
\text { (Students) }\end{array}$ & $\begin{array}{l}\text { Percentage } \\
(\%)\end{array}$ & $\begin{array}{l}\text { Interviewee } \\
\text { Frequency } \\
\text { (Students) }\end{array}$ & $\begin{array}{l}\text { Percentage } \\
(\%)\end{array}$ \\
\hline 1 & Very Active & 4 & 100 & 14 & 70 \\
2 & Active & 0 & 0 & 0 & 0 \\
3 & Fairly Active & 0 & 0 & 2 & 30 \\
4 & Less Active & 0 & 0 & 0 & 0 \\
5 & Silent & 0 & 0 & 0 & 0 \\
\hline Total & 10 & 100 & 16 & 100 \\
\hline
\end{tabular}

In the second type of interview, the data shows that all the students very active speaking English in the interview. There were $14(70 \%)$ students very active as the interviewees and only $2(30 \%)$ students confuse or silent in this type.

\section{The third type of interview technique}

The participants were grouped into four. Each group consists of five participants sitting in round. Four participants became interviewers and one participant became interviewee. The participants applied the interview for 30 minutes. The active participants as interviewers and interviewees were recorded and analyzed in the table 3 as follows: 
Table 3. The active participants of the interview in group

\begin{tabular}{llllll}
\hline No. & Qualification & $\begin{array}{l}\text { Interviewer } \\
\text { Frequency } \\
\text { (Students) }\end{array}$ & $\begin{array}{l}\text { Percentage } \\
(\%)\end{array}$ & $\begin{array}{l}\text { Interviewee } \\
\text { Frequency } \\
\text { (Students) }\end{array}$ & $\begin{array}{l}\text { Percentage } \\
(\%)\end{array}$ \\
\hline 1 & Very Active & 14 & 70 & 4 & 100 \\
2 & Active & 0 & 0 & 0 & 0 \\
3 & Fairly Active & 2 & 30 & 0 & 0 \\
4 & Less Active & 0 & 0 & 0 & 0 \\
5 & Silent & 0 & 0 & 0 & 0 \\
\hline Total & & 16 & 100 & 4 & 100 \\
\hline
\end{tabular}

The data shows that there were $14(70 \%)$ students very active as interviewers and $2(30 \%)$ were confuse or silent in this type of interview. There were $4(100 \%)$ students very active as interviewees and there was not student active, fairly active, less active, confuse or silent in applying the interview technique.

\section{Control Class Data}

Based on the observation checklist during the control class, the data were collected to identify the active and none active students in speaking English in the traditional class for sixty minutes were shown in the table 4 as follows:

Table 4. The active participants of the control class

\begin{tabular}{llll}
\hline No & Qualification & $\begin{array}{l}\text { Frequency } \\
\text { (Student) }\end{array}$ & $\begin{array}{l}\text { Percentage } \\
\text { (\%) }\end{array}$ \\
\hline 1 & Very Active & 12 & 60 \\
2 & Active & 0 & 0 \\
3 & Fairly Active & 2 & 30 \\
4 & Less Active & 0 & 0 \\
5 & Silent & 8 & 40 \\
\hline Total & & 16 & 100 \\
\hline
\end{tabular}

The table above shows that the participants in the control class were in the fairly active classification which scores $60 \%$ of the participants active in speaking English such as; in telling story, describing and also in asking or responding the questions from the participants in the class. There were 12(60\%) participants were very active speaking English in the class and there were $8(40 \%)$ of the participants just keep silent in this type of traditional teaching method.

\section{Discussion}

The data analysis of the experimental class shows that the participants have good attitude toward the pair and group interview techniques. The participants' attitude score through the questionnaire to the three types of interview techniques indicated that the classification mean score is $92.85 \%$, it means that the participants have very high attitude. It shows that the pairs 
and groups of interview techniques effective enhance the students' stimulus in speaking English actively in the groups. The three group types in which in pair and the two groups in five participants in which one student asked the four participants as interviewees and the four participants as interviewers asked the one participant as interviewee are more effective enhance the participants' stimulus to speak actively.

All the participants spoke actively in the groups of treatment class. While, in the control class only $12(60 \%)$ of twenty participants were active in speaking English during the class for sixty minutes. The way of teaching in the control class and the traditional technique used such as; written exercises, structure rule is difference from the experiment class. The way of teaching has great influence for the students' attitude. Some previous researchers have conducted the different ways of pair and group activities such as; Murad (2017) found that the most of the teachers at Zakho city are aware of the English teaching model but still confuses which one have to in teaching the Sunrise curriculum.

The study also identified that using classical methods in teaching a curriculum design based on CLT approach is effective. This study also shows that most of the teachers need improvement in their teaching practices. Moreover, Ha Mi, et al. (2008) found that pair and group interview techniques processing improved the participants speaking competences and made them free and confident in speaking English. Furthermore, Hamzah (2005), found that the students' speaking getting improvement through individual activities and group. Those research types are different from the pair and groups interview techniques.

The data analysis of the observation checklist in this experimental class research shows that all the participants were very active and more confident in speaking English to the pairs and groups interview techniques. They involved their English speaking actively during the research treatment, whereas the data analysis of the control group shows that the participants were less active and low confident in asking and responding. They were scare and felt shy to express their idea in speaking English, some participants merely keep silent in this traditional model.

The data analysis both the control and treatment classes can be seen in the comparison diagram as follows:

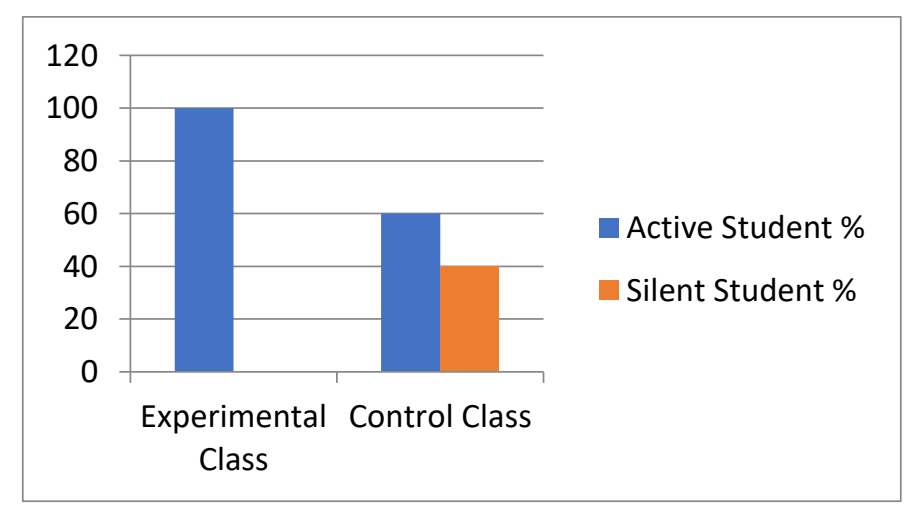

Figure 1. Comparison Chart of Experimental and control Class

Based on the diagram above, the data shows that there are significant differences of the experimental class that was given treatment from the big control class that taught through traditional method. The experimental class data analysis indicated that there were $18(90 \%)$ of the students very active and only $2(10 \%)$ of the students fairly active in the speaking class, 
it means that all of the students were active in speaking English in the class, whereas the control class data analysis only $12(60 \%)$ of the students very active, and $8(40 \%)$ of the students kept silent in applying the traditional teaching method.

The data analysis of the research indicated that most of the participants in the treatment class speaking actively in the class. The participants' attitude toward the pair and group interview techniques through questionnaire shows that the mean score is 92.85 percent, in which the students' positive attitude means score is $\mathbf{4 7 . 5 5}$ percent and negative attitude mean score is 45.30 percent. This indicated that the participants have very high attitude through pair and group interview techniques. The classification score shows that the students were very active, more confident, and more fluent in speaking English through the pairs and groups interview techniques than the traditional teaching model in the control class.

The researcher identified that the hypotheses testing result in this research through pair and group interview techniques is effective to enhance the participants' stimulus in speaking English freely and bravely along the group session. Based on the data analysis above shows that the first hypotheses is accepted in which the treatment class shows that the participants speaking English more actively than the control class. And the second hypotheses also indicates that pair and group interview techniques enhanced the participants stimulus in speaking competences actively, confidently and fluently than the traditional model in the control class.

\section{Conclusion}

The study identified that teaching English through the pairs and two types of group interview techniques are effective in stimulating the participants speaking skill in the class. The first session in which one participant became an interviewer and four participants became interviewees. Second session were four participants became interviewees and one participant as interviewee. These models made the participants spoke English freely and bravely in this situation. Moreover, the other results show that the participants became more confident, active, and fluent in English speaking activities during the class. These pair and group interview techniques model are quite different from the traditional and other group models teaching.

\section{Acknowledgment}

I thank goes to the Ministry of Research, Technology and Higher Education (DIKTI) as supporting government funding in this research.

\section{References}

Cahya, P. (2017). The Correlation between Students' L2 Motivation and Their EFL Proficiency. Ethical Lingua: Journal of Language Teaching and Literature, 4(2), 176183. https://doi.org/10.30605/ethicallingua.v4i2.633

De Bot, K., \& Lowie, W. (2005) Second Language Acquisition. USA. Routledge.

Esmaeeli, Z., Sabet, M. K., \& Shahabi, Y. (2018). The Relationship between Emotional Intelligence and Speaking Skills of Iranian Advanced EFL Learners. International Journal of Applied Linguistics and English Literature, 7(5), 22-28.

https://dx.doi.org/10.7575/aiac.ijalel.v.7n.5p.22 
Gay, L. R. (1981). Educational Research Second edition. Charles E. Merrill Publishing Company A Bell \&Howell Company. Columbus, Ohio. USA

Ha Mi, Pham Thi., Kim Thanh, Nguyen. (2008). Pair Work-Group Work and Its Implementation In Teaching Speaking for $10^{\text {th }}$ Graders of Public High Schools. Ho Chi Minh City University.

Hamzah, M. H. (2005) Eaching Speaking Skills through Group Work Activities. Universiti Teknologi Malaysia.

Harkness, J. A., Van de Vijver, F. J. R., Mohler, P. Ph. (2003). Cross-Cultural Survey Methods. Hoboken, New Jersey. John Wiley \& Sons

Labov, W. (2006). The social stratification of English in New York. USA. University Press. New York

Lehmann, W. P. (2006), The Role of Intercultural Studies in the Development of Linguistics. Linguistics Research Center, University of Texas. Austin.

Liao, G. (2009). Improvement of Speaking Ability through Interrelated Skills. English Language Teaching, 2(3), 11-14.

Martinez, R., April, Y. C., Shen, S. K., \& Yoon, S. (2003). International System Technology (IST) Graduated Student Attitudes Towards Group Work. Indiana University.

Moulton, W. G. (1961). Linguistic and Language Teaching. United States. Princeton University.

Murad, I. H. (2017). Investigating English Teachers' Awareness of the Teaching Methods That Should be used in Teaching the Sunrise Series in Zakho City, Duhok-Iraq. Humanities Journal of University of Zakho, 5(1), 239. https://doi.org/10.26436/2017.5.1.193

Nation, I. S. P. (1977). Language Teaching Techniques. Third Edition. Victoria University of Wellington

Potaka, L., \& Cochrane, S. (2004). Developing bilingual questionnaire. New Zealand. Maori language survey.

Rakab, M. B. (2016). Pair -Work and Group-Work Activities: Myth or Reality? International Journal of Educational Investigations, 3(6), 82-100.

Soldado, R. M., Megías, M. G., \& Haywood, J. (2013). Reconocimiento del aprendizaje abierto en las universidades tradicionales [Open learning universities recognition in traditional]. Journal for Educators, Teachers and Trainers, 4(2), 82-94.

Sura, N. A. (2012). Teacher's Strategies in Language Classroom. Middle-East Journal of Scientific Research, 12(9), 1224-1230.

Thayyib, M. (2019). The Betterment of Group Dynamics in Theory of Translation Class through Lesson Study. Ethical Lingua: Journal of Language Teaching and Literature, 6(2), 86-97. https://doi.org/10.30605/25409190.v6.86-97

Teng, M. F. (2020). The effectiveness of group, pair and individual output tasks on learning phrasal verbs. Language Learning Journal, 48(2), 187-200. https://doi.org/10.1080/09571736.2017.1373841

Tuan, L. T. (2010). Teaching English Discrete Sounds through Minimal Pairs. Journal of Language Teaching and Research, 1(5), 540-561. https://doi/org/10.4304/jltr.1.5.540561 